\title{
Analisis Kinerja Fasilitas Pejalan Kaki Dengan Metode Quality Function Deployment (Studi Kasus Bintaro Jaya Xchange - Stasiun Jurangmangu)
}

\author{
Vania Armila Pratiwi ${ }^{1, *}$, Fredy Jhon Philip Sitorus ${ }^{2}$ \\ ${ }^{1}$ Department of Civil Engineering, Universitas Pembangunan Jaya \\ South Tangerang, Banten 15413, Indonesia \\ vaniaarmilapratiwi@gmail.com \\ ${ }^{2}$ Department of Civil Engineering, Universitas Pembangunan Jaya \\ South Tangerang, Banten 15413, Indonesia \\ fredy.jhon@upj.ac.id
}

Received 29 August 2019, Revised 15 September 2019, Accepted 25 September 2019

\begin{abstract}
Transportation infrastructure is an important component that should be built and designed properly according to principles of safety, one of which is a pedestrian facility. The construction of pedestrian facilities is strongly needed in an effort to meet the needs of urban communities using mass public transportation. The aim of this study is to determine the service performance of pedestrian walkway connecting the train station to the transit area and shopping centers. Moreover, based on the results of the analysis of the level of performance and importance, a pedestrian facility improvement plan is carried out using the Quality Function Deployment (QFD) method. In this research, the data collection method is observation in the field and gathering information from respondents with questionnaires. The results showed that the walkway facilities at Jurangmangu station were classified as category A. From the results of the important performance analysis method, found that respondents were satisfied with the facilities provided but there were several attributes that had poor service performance. The results of the QFD analysis recommend to improve services that must be carried out, that is the addition of pedestrian bridge, special lanes for persons with disabilities, seats and rest areas, checking and repairing lighting, places for parking vehicles, trash bins at some point, optimizing available facilities, addition of security personnel, and completing the lack of guidance signs.
\end{abstract}

Keywords: Pedestrian, Station, QFD method, Service performance

\begin{abstract}
Abstrak - Infrastruktur transportasi merupakan komponen penting yang harus dibangun dan dirancang dengan baik sesuai dengan prinsip-prinsip keselamatan, salah satunya adalah fasilitas pejalan kaki. Pembangunan fasilitas pejalan kaki sangat diperlukan dalam upaya memenuhi kebutuhan masyarakat perkotaan yang menggunakan angkutan umum massal. Tujuan penelitian ini adalah untuk mengetahui kinerja pelayanan lajur pejalan kaki yang menghubungkan stasiun kereta api menuju area peralihan moda transportasi dan pusat perbelanjaan. Selain itu berdasarkan hasil analisis tingkat kinerja dan kepentingan maka dilakukan rencana perbaikan fasilitas pejalan kaki menggunakan metode Quality Function Deployment (QFD). Metodenya adalah pengamatan di lapangan serta penyebaran kuisioner kepada responden. Hasil studi menunjukkan bahwa fasilitas lajur pejalan kaki di stasiun Jurangmangu tergolong kategori A. Dari hasil metode important performace analysis menyatakan bahwa responden merasa puas dengan pelayanan fasilitas yang disediakan namun terdapat beberapa atribut yang memiliki kinerja pelayanan kurang baik. Hasil analisis dengan metode QFD rekomendasikan untuk meningkatkan pelayanan yang harus dilakukan yaitu penambahan jembatan penyebrangan, jalur khusus untuk penyandang disabilitas, kursi dan tempat istirahat, memeriksa dan memperbaiki lampu penerangan, tempat untuk kendaraan parkir, tempat sampah pada beberapa titik, optimalisasi fasilitas yang sudah tersedia, penambahan petugas keamanan, dan melengkapi kekurangan rambu petunjuk.
\end{abstract}

Kata Kunci: Pejalan kaki, Stasiun, Metode QFD, Kinerja pelayanan

\section{PENDAHULUAN}

Pertumbuhan kawasan perkotaan di Indonesia khususnya di Jakarta dan kawasan penyangga seperti Bekasi, Bogor dan Tangerang sangat masif. Hal ini ditunjukkan dengan semakin berkembangnya infrastruktur di daerah penyangga seperti perumahan, pusat perbelanjaan dan area komersil lainnya. Untuk menunjang kegiatan masyarakat tersebut sangat diperlukan sistem layanan angkutan umum yang efisien dalam melayani kebutuhan pergerakan. 
Pembangunan sistem angkutan umum harus memperhatikan integrasi antar moda sehingga meningkatkan keinginan masyarakat untuk menggunakan angkutan umum massal seperti kereta KRL, BRT, ataupun MRT. Oleh karena itu ketersediaan lajur pejalan kaki menjadi salah satu aspek penting dalam keberhasilan sistem angkutan massal terutama di area transit.

Fasilitas pejalan kaki merupakan sarana yang sangat diperlukan bagi masyarakat khususnya perkotaan untuk melakukan kegiatannya. Oleh karena itu, fasilitas ini hendaknya dibangun dengan mempertimbangkan karakteristik pejalan kaki sehingga dapat melakukan perjalanan yang aman, nyaman dan lancar.

Beberapa kajian mengenai pejalan kaki di beberapa kota besar di Asia menyatakan bahwa standar perencanaan fasilitas pejalan kaki untuk negara-negara Asia sebaiknya berdasarkan pada karakteristik lokal pejalan kaki. Oleh karena itu, standar perancangan lokal dibutuhkan pada fasilitasfasilitas pejalan kaki walaupun terdapat anggapan bahwa berjalan kaki juga dianggap bukanlah salah satu moda transportasi yang patut dipertimbangkan. Menurut Utterman (1984), pada dasarnya setiap orang adalah pejalan kaki.

Fasilitas pejalan kaki harus direncanakan dengan baik dan harus digunakan sesuai dengan fungsinya sehingga menimbulkan rasa nyaman bagi pejalan kaki. Perencanaan akan kebutuhan jalur pedestrian harus direncanakan dengan baik sesuai ketentuan dan standar aturan perencanaan jalur pedestrian dengan mempertimbangkan dan mengutamakan aspek keselamatan dan kenyamanan pejalan kaki.

Bintaro sebagai salah satu kawasan yang berada di wilayah Tangerang Selatan merupakan wilayah yang memiliki kebutuhan terhadap pejalan kaki yang cukup tinggi. Hal ini karena Bintaro merupakan daerah permukiman yang memiliki fasilitas angkutan publik yang cukup lengkap, salah satunya kereta api commuter line. Menurut Badan Pusat Statistik Kota Tangerang Selatan pada tahun 2017 menunjukkan penduduk Tangerang Selatan berjumlah 1.593.812 jiwa dengan jumlah usia kerja mencapai 75 persen.

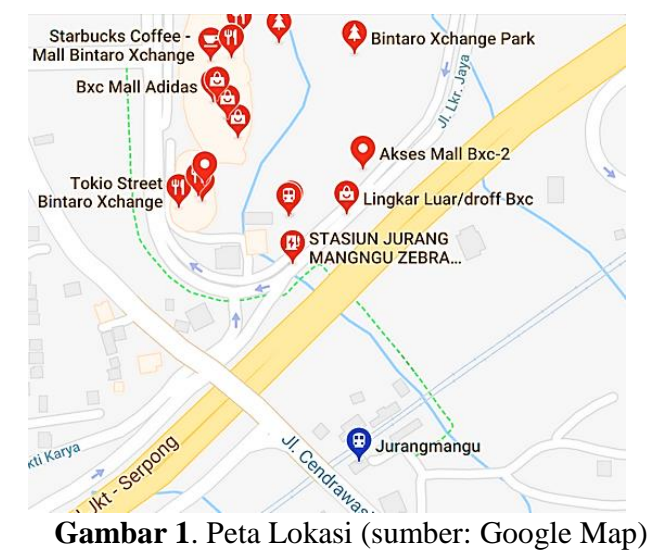

Salah satu fasilitas pejalan kaki yang dibangun untuk mengakomodasi kebutuhan pengguna KRL adalah akses stasiun Jurangmangu - Bintaro Jaya Xchange. Dimana fasilitas ini bertujuan sebagai akses bagi pengguna KRL yang akan beralih ke moda transportasi lain seperti ojek online maupun bus.

\section{Latar Belakang}

Kawasan Bintaro sebagai area pemukiman yang memiliki akses angkutan massal seperti KRL perlu ditunjang dengan pengembangan fasilitas pendukung yang ramah terhadap pejalan kaki. Hal ini bertujuan untuk meningkatkan minat warga Bintaro terhadap penggunaan kereta commuter.

\section{Rumusan Masalah}

Pada stasiun Jurangmangu telah dibangun fasilitas pejalan kaki menuju Lingkar Bintaro Jaya Xchange dengan tujuan untuk perpindahan moda transportasi ataupun ke pusat perbelanjaan Mall Bxchange. Fasilitas pejalan kaki tersebut perlu dievaluasi sesuai dengan tingkat pelayanan yang diharapkan sehingga dapat ditingkatkan hingga mencapai kualitas pelayanan yang optimal.

\section{Tujuan Penelitian}

Tujuan dari penelitian ini adalah untuk mengetahui karakteristik pejalan kaki dan kinerja pelayanan fasilitas penunjang jalur pejalan kaki sesuai standar yang telah ditentukan, menganalisis tingkat kenyamanan dan kepuasan pengguna jalur pejalan kaki terhadap kondisi jalur pejalan kaki serta menyusun rekomendasi untuk meningkatkan kualitas pelayanan terhadap fasilitas pejalan kaki yang belum memenuhi kepuasan pejalan kaki.

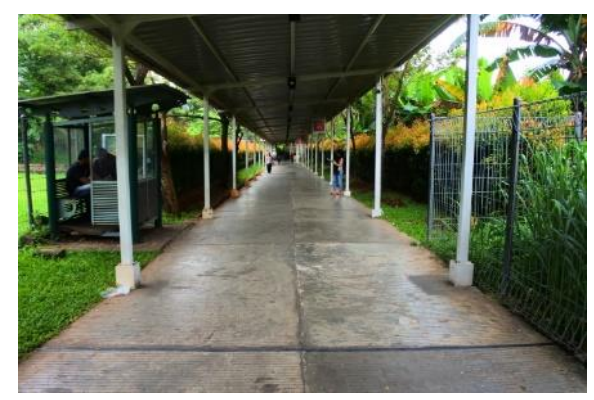

Gambar 2. Obyek studi penelitian

\section{STUDI PUSTAKA}

\section{Pejalan Kaki dan Karakteristiknya}

Menurut UU No. 22 Tahun 2009 definisi dari pejalan kaki adalah setiap orang yang berjalan di ruang lalu lintas jalan. Berjalan merupakan merupakan salah satu jenis transportasi nonkendaraan yang menyehatkan.

Menurut Peraturan Menteri pekerjaan Umum Nomor 03/PRT/M/2014 kebutuhan ruang jalur pejalan kaki untuk berdiri dan berjalan dihitung berdasarkan dimensi tubuh manusia. Dimensi tubuh yang lengkap berpakaian adalah $45 \mathrm{~cm}$ untuk tebal 
tubuh sebagai sisi pendeknya dan $60 \mathrm{~cm}$ untuk lebar bahu sebagai sisi panjangnya.

Parameter yang digunakan menurut Peraturan Menteri Pekerjaan Umum Nomor 03/PRT/M/2014 dalam analisis kelayakan pejalan kaki antara lain kecepatan pejalan kaki, arus rata-rata pejalan kaki dan kepadatan pejalan kaki.Untuk mengevaluasi desain fasilitas pejalan kaki yaitu kecepatan, arus dan kerapatan pejalan kaki, maka diperlukan pemahaman karakteristik arus pejalan kaki yang dipengaruhi oleh keberadaan tipe fasilitas seperti ruas jalan dan koridor, kawasan CBD (Guio, Duenas \& Dias, 2014), fasilitas kampus (Shekari, Moeinaddini \& Shah, 2014), terminal penumpang yang berdekatan dengan terowongan (Yang et al., 2010)

\section{Kualitas Pelayanan Fasilitas Jalur Pejalan Kaki}

Fasilitas pejalan kaki adalah semua bangunan yang disediakan untuk pejalan kaki untuk memberikan pelayanan terhadap pejalan kaki dengan memberikan kelancaran, keamanan dan kenyamanan, serta keselamatan. Menurut UU tentang Lalu Lintas Jalan No. 22 Tahun 2009 menyatakan bahwa setiap jalan yang digunakan untuk lalu lintas umum harus dilengkapi dengan perlengkapan jalan, salah satunya berupa fasilitas pejalan kaki.

Tingkat pelayanan terhadap fasilitas pejalan kaki umumnya dinyatakan berdasarkan kapasitas dan volume pejalan kaki. Faktor seperti ukuran tubuh, tipe aliran pejalan kaki dan dimensi pejalan kaki telah dipertimbangkan untuk menjelaskan kualitas pelayanan. Dalam beberapa tahun terakhir, beberapa studi juga telah mempertimbangkan faktor lingkungan, daya tarik jalan serta pembangunan di area sekitar lajur trotoar (Laxman, Rasdtogi \& Chandra, 2010). Fasilitas pejalan kaki yang baik tentu akan menjadi daya tarik bagi masyarakat untuk berjalan kaki, dimana tingkat kenyamanan merupakan fungsi dari kebutuhan ruang yang dipenagruhi oleh persepsi pejalan kaki (Cepolina, Pederico \& Paloma, 2018).

\section{METODE PENELITIAN \\ Data dan Lokasi Penelitian}

Penelitian ini dilakukan pada fasilitas jalur pejalan kaki yang menghubungkan stasiun Jurangmangu dengan kawasan Lingkar BxChange. Proses pengambilan data dalam penelitian ini menggunakan teknik pengamatan (observasi), pengamatan dalam penelitian ini dilakukan secara langsung ke lokasi penelitian. Pengamatan yang dilakukan untuk memperoleh data geometri jalur pejalan kaki dan karakteristik pejalan kaki. Sedangkan untuk mengetahui tingkat kepuasan pejalan kaki, pengambilan data dilakukan dengan penyebaran kuisioner. Kemudian metode pengambilan data lainnya berupa metode dengan teknik wawancara terhadap narasumber. Hal ini dimaksud untuk memberikan evaluasi hasil kinerja pelayanan dari fasilitas pejalan kaki.

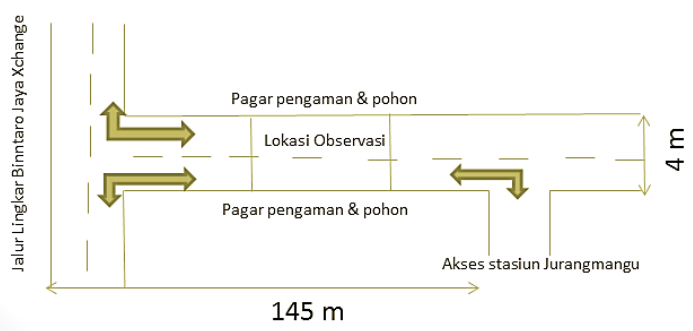

Gambar 3. Layout area pengamatan

\section{Pengolahan Data}

Metode pengolahan data dilakukan dengan metode kuantitatif dimana penyajian data merupakan hasil dari input data yang diperoleh dari observasi di lapangan. Penyajian data berupa karakteristik dan perilaku pejalan kaki dilakukan dengan pendekatan statistik deskriptif, kemudian tingkat kepuasan dan kepentingan diperoleh dengan menggunakan metode penilaian kualitas jasa yaitu Important Performance Analysis (IPA). Kemudian atribut yang diperlukan peningkatan layanan menurut metode IPA akan dianalisis lebih lanjut untuk memperoleh suatu rekomendasi terhadap peningkatan kualitas pelayanan dengan metode Quality Function Deployment (QFD) (Rifela, 2017).

\section{HASIL DAN PEMBAHASAN}

Berdasarkan data rata-rata jumlah penumpang pada waktu sibuk setiap harinya berkisar 10.572 penumpang ,sehingga besarnya jumlah sampel menurut Tabel Isaac dan Michael yaitu 335 responden. Karakteristik sampel terdiri dari 57\% wanita dan $43 \%$ pria dengan proporsi usia di bawah 21 tahun sebesar $27 \%$, usia 21 - 30 tahun sebesar $62 \%$ serta berusia di atas 30 tahun sebesar $11 \%$. Karaktersitik lain dari responden diperlihatkan pada Gambar 4.

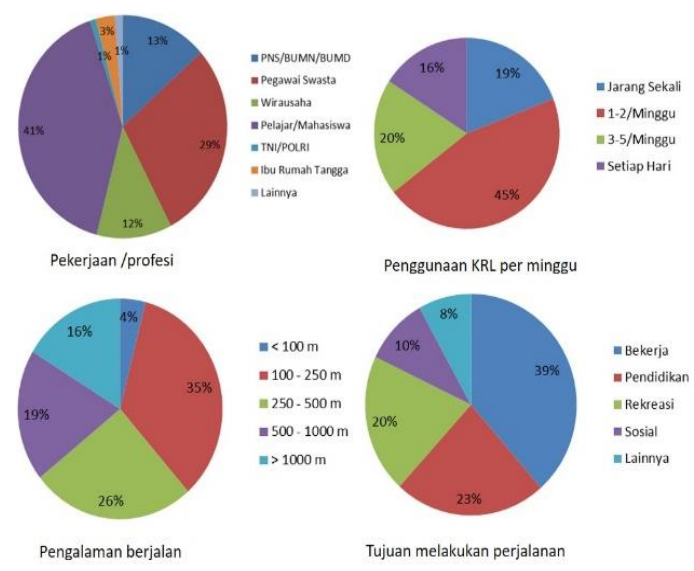

Gambar 4. Karakteristik responden

Berdasarkan hasil pengamatan di lapangan, volume pajalan kaki dalam 3 periode waktu pada jalur pejalan kaki Lingkar Bintaro Jaya Xchange 
menunjukkan bahwa volume terpadat terjadi pada waktu sore hari yaitu pukul 16.00-19.00 dimana volume dalam 15 menit terdapat 550 pejalan kaki dan volume pejalan kaki dalam satu jam yaitu 1899. Pada sore hari menjadi jam terpadat dan tersibuk karena selain jam pulang kerja pada sore hari merupakan arus balik yang membuat setiap pengguna kereta api turun dalam waktu yang sama dan membuat jalur pejalan kaki menjadi lebih padat dari pada pagi dan siang hari.

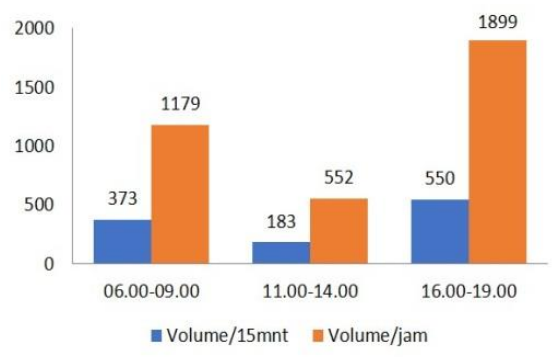

Gambar 5. Data volume pejalan kaki

Kecepatan berdasarkan jenis kelamin adalah kecepatan seorang pejalan kaki dalam berjalan kaki dari titik yang sudah dijadikan lokasi untuk observasi yaitu dengan panjang 12 meter, terbagi menjadi perempuan dan laki-laki. Rata-rata kecepatan pejalan kaki laki-laki pada jalur pejalan kaki Lingkar Bintaro Jaya Xchange akses stasiun Jurangmangu adalah $1,557 \mathrm{~m} /$ detik, sedangkan kecepatan rata-rata pejalan kaki perempuan saat berjalan adalah 1,353 m/detik.

Tabel 1. Karakteristik kecepatan pejalan kaki

\begin{tabular}{ccc}
\hline Periode & \multicolumn{2}{c}{ Kecepatan Pejalan Kaki $(\mathbf{m} / \mathbf{d t k})$} \\
& Wanita & Pria \\
\hline $\mathbf{0 6 . 0 0}-\mathbf{0 9 . 0 0}$ & 1.44 & 1.64 \\
$\mathbf{1 1 . 0 0}-\mathbf{1 4 . 0 0}$ & 1.31 & 1.50 \\
$\mathbf{1 6 . 0 0}-\mathbf{1 9 . 0 0}$ & 1.33 & 1.53 \\
Rata-rata & 1.353 & 1.557 \\
\hline
\end{tabular}

Sedangkan untuk arus pejalan kaki dan kepadatan pejalan kaki ditunjukkan pada Tabel 2. Dimana arus pejalan kaki terpadat selama lima belas menit terjadi pada pukul 18.45 - 19.00 yaitu 37 orang setiap menitnya dan kepadatan tertinggi terjadi pada periode pukul $16.00-19.00$.

Tabel 2. Arus dan kepadatan pejalan kaki

\begin{tabular}{ccc}
\hline Periode & $\begin{array}{c}\text { Arus pejalan } \\
\text { kaki } \\
\text { (ped/menit) }\end{array}$ & $\begin{array}{c}\text { Kepadatan } \\
\text { pejalan kaki } \\
\text { (m2/ped) }\end{array}$ \\
\hline $\mathbf{0 6 . 0 0 - \mathbf { 0 9 . 0 0 }}$ & 25 & 16 \\
$\mathbf{1 1 . 0 0}-\mathbf{1 4 . 0 0}$ & 12 & 24 \\
$\mathbf{1 6 . 0 0}-\mathbf{1 9 . 0 0}$ & 37 & 12 \\
Rata-rata & 1.353 & 1.557 \\
\hline
\end{tabular}

Berdasarkan Peraturan Menteri Pekerjaan Umum Nomor: 03/PRT/2014, maka dihitung luas jalur pejalan kaki untuk setiap pejalan kaki. Kemudian dapat ditentukan bahwa standar jalan pada jalur pejalan kaki Lingkar Bintaro Jaya Xchange akses stasiun Jurangmangu adalah masuk dalam Standar A, dimana para pejalan kaki masih dapat berjalan dengan

nyaman dan cepat tanpa mengganggu pejalan kaki lainnya, namum keberadaan pejalan kaki lainnya sudah mulai berpengaruh pada arus pejalan kaki. Luas jalur pejalan kaki $\geq 12 \mathrm{~m}^{2}$ /orang dengan arus pejalan kaki $<16$ orang/menit/meter.

Dari uji validasi terhadap hasil penyebaran kuisioner kepada responden mengenai tingkat kepuasan dan tingkat kepentingan menunjukkan bahwa semua variabel memiliki nilai $r_{\text {hitung }}$ lebih besar dariada $r_{\text {tabel }}$. Hal ini menunjukkan bahwa semua variabel adalah valid.

Tabel 3. Hasil uji validasi variabel kepuasan

\begin{tabular}{|c|c|c|c|c|c|}
\hline Variabel & $\begin{array}{l}\text { Indikator } \\
\text { Variabel }\end{array}$ & $\begin{array}{c}\text { No } \\
\text { Atribut }\end{array}$ & $\mathrm{r}_{\text {hit }}$ & $\mathrm{r}_{\text {tabel }}$ & Ket. \\
\hline \multirow{7}{*}{ 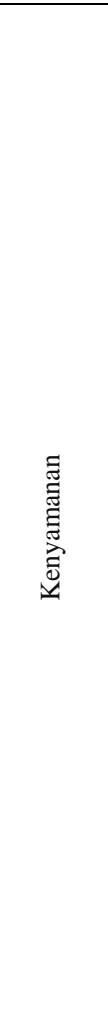 } & $\begin{array}{l}\text { Pelindung } \\
\text { terhadap cuaca } \\
\text { (pohon, kanopi } \\
\text { dll) }\end{array}$ & $\mathrm{X} 1$ & 0.650 & 0.128 & valid \\
\hline & $\begin{array}{l}\text { Adanya kursi } \\
\text { atau tempat } \\
\text { istirahat untuk } \\
\text { pejalan kaki }\end{array}$ & $\mathrm{X} 2$ & 0.432 & 0.128 & valid \\
\hline & $\begin{array}{l}\text { Lebar trotoar } \\
\text { yang } \\
\text { memudahkan } \\
\text { pergerakan }\end{array}$ & $\mathrm{X} 3$ & 0.633 & 0.128 & valid \\
\hline & $\begin{array}{l}\text { Keterhubungan } \\
\text { trotoar }\end{array}$ & $\mathrm{X} 4$ & 0.678 & 0.128 & valid \\
\hline & $\begin{array}{l}\text { Permukaan } \\
\text { jalan rata, tidak } \\
\text { naik turun dan } \\
\text { kemiringan } \\
\text { yang cukup } \\
\text { landai }\end{array}$ & X5 & 0.639 & 0.128 & valid \\
\hline & $\begin{array}{l}\text { Tidak ada } \\
\text { penghalang } \\
\text { seperti } \\
\text { pedagang kaki } \\
\text { lima, warung, } \\
\text { kendaraan } \\
\text { parkir dll }\end{array}$ & X6 & 0.602 & 0.128 & valid \\
\hline & $\begin{array}{l}\text { Tersedianya } \\
\text { jalur khusus } \\
\text { untuk } \\
\text { penyandang } \\
\text { disabilitas }\end{array}$ & $X 7$ & 0.411 & 0.128 & valid \\
\hline \multirow{3}{*}{ 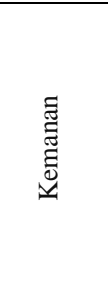 } & $\begin{array}{l}\text { Keberadaan } \\
\text { lampu } \\
\text { penerang jalan }\end{array}$ & X8 & 0.742 & 0.128 & valid \\
\hline & $\begin{array}{l}\text { Lingkungan } \\
\text { yang terhindar } \\
\text { dari tindak } \\
\text { kriminal }\end{array}$ & X9 & 0.677 & 0.128 & valid \\
\hline & $\begin{array}{l}\text { Pandangan } \\
\text { tidak terhalang }\end{array}$ & X10 & 0.684 & 0.128 & valid \\
\hline \multirow{4}{*}{ 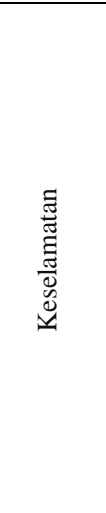 } & $\begin{array}{l}\text { Ketersediaan } \\
\text { trotoar yang } \\
\text { memadai }\end{array}$ & $\mathrm{X} 11$ & 0.719 & 0.128 & valid \\
\hline & $\begin{array}{l}\text { Ketersediaan } \\
\text { jembatan } \\
\text { penyeberangan }\end{array}$ & $\mathrm{X} 12$ & 0.231 & 0.128 & valid \\
\hline & $\begin{array}{l}\text { Ketersediaan } \\
\text { zebra cross } \\
\text { untuk } \\
\text { menyeberang }\end{array}$ & X13 & 0.737 & 0.128 & valid \\
\hline & $\begin{array}{l}\text { Keberadaan } \\
\text { pembatas atau } \\
\text { pemisah lajur } \\
\text { pejalan dengan } \\
\text { lalu lintas } \\
\text { kendaraan }\end{array}$ & X14 & 0.676 & 0.128 & valid \\
\hline
\end{tabular}




\begin{tabular}{|c|c|c|c|c|c|}
\hline & $\begin{array}{l}\text { Tidak ada } \\
\text { lubang yang } \\
\text { menyebabkan } \\
\text { bahaya } \\
\text { terperosok atau } \\
\text { tersandung } \\
\text { Permukaan } \\
\text { trotoar tidak } \\
\text { licin yang } \\
\text { mengakibatkan } \\
\text { terpeleset } \\
\text { Tidak ada pot, } \\
\text { pohon atau } \\
\text { tiang yang } \\
\text { menyebabkan } \\
\text { bahaya } \\
\text { kecelakaan }\end{array}$ & X17 & 0.656 & 0.128 & valid \\
\hline 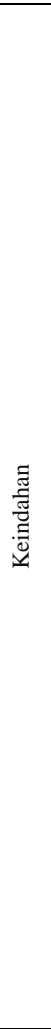 & $\begin{array}{l}\text { Desain trotoar } \\
\text { tampak } \\
\text { kontras, } \\
\text { harmonis dan } \\
\text { menarik } \\
\text { dengan } \\
\text { lingkungan } \\
\text { sekitar } \\
\text { Desain sarana } \\
\text { penyeberangan } \\
\text { tampak } \\
\text { kontras, } \\
\text { harmonis dan } \\
\text { menarik } \\
\text { dengan } \\
\text { lingkungan } \\
\text { sekitar } \\
\text { Desain fasilitas } \\
\text { penunjang } \\
\text { (halte, bangku, } \\
\text { tempat sampah, } \\
\text { rambu petunjuk } \\
\text {, jalan hijau, } \\
\text { lampu } \\
\text { penerangan) } \\
\text { tampak tampak } \\
\text { kontras, } \\
\text { harmonis dan } \\
\text { menarik } \\
\text { dengan } \\
\text { lingkungan } \\
\text { sekitar }\end{array}$ & X19 & 0.656 & 0.128 & valid \\
\hline
\end{tabular}

Tabel 4 . Hasil uji validasi variabel kepuasan

\begin{tabular}{|c|c|c|c|c|c|}
\hline $\begin{array}{l}\text { Varia- } \\
\text { bel }\end{array}$ & $\begin{array}{l}\text { Indikator } \\
\text { Variabel }\end{array}$ & $\begin{array}{c}\text { No } \\
\text { Atribut }\end{array}$ & $\mathrm{r}_{\text {hit }}$ & $\mathrm{r}_{\text {tabel }}$ & Ket. \\
\hline \multirow{5}{*}{ 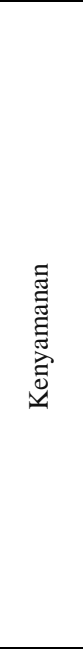 } & $\begin{array}{l}\text { Pelindung } \\
\text { terhadap cuaca } \\
\text { (pohon, kanopi } \\
\text { dll) }\end{array}$ & $\mathrm{Y} 1$ & 0.566 & 0.128 & valid \\
\hline & $\begin{array}{l}\text { Adanya kursi } \\
\text { atau tempat } \\
\text { istirahat untuk } \\
\text { pejalan kaki }\end{array}$ & Y2 & 0.500 & 0.128 & valid \\
\hline & $\begin{array}{l}\text { Lebar trotoar } \\
\text { yang } \\
\text { memudahkan } \\
\text { pergerakan }\end{array}$ & Y3 & 0.600 & 0.128 & valid \\
\hline & $\begin{array}{l}\text { Keterhubungan } \\
\text { trotoar }\end{array}$ & Y4 & 0.502 & 0.128 & valid \\
\hline & $\begin{array}{l}\text { Permukaan } \\
\text { jalan rata, tidak } \\
\text { naik turun dan } \\
\text { kemiringan } \\
\text { yang cukup } \\
\text { landai }\end{array}$ & Y5 & 0.579 & 0.128 & valid \\
\hline
\end{tabular}

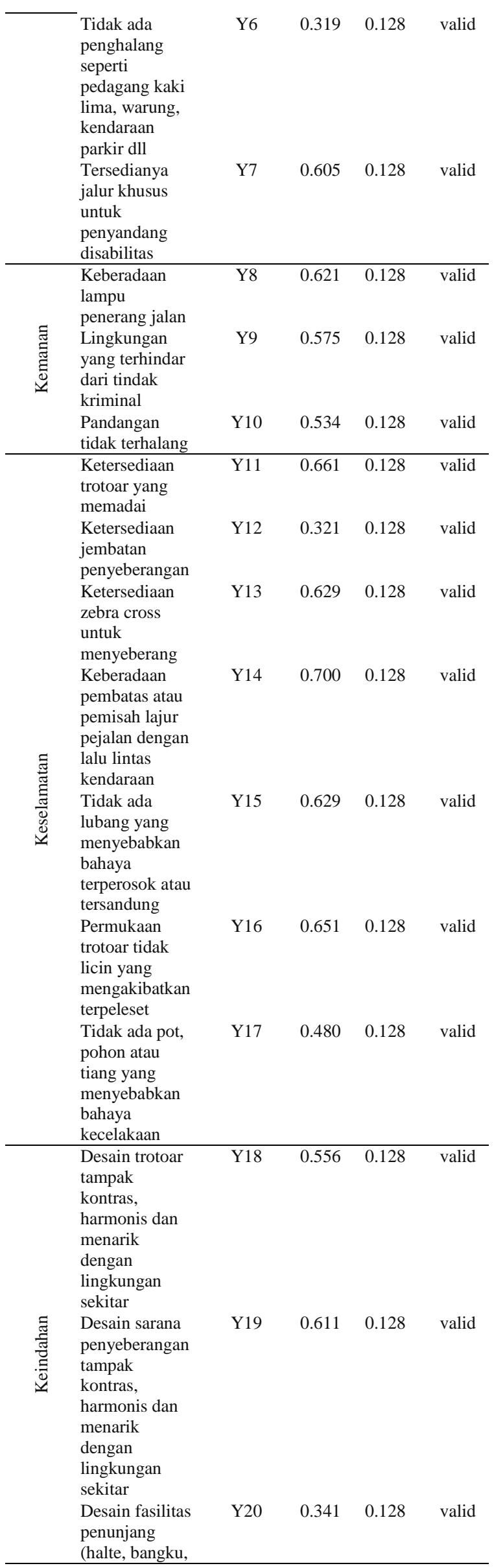


tempat sampah,

rambu

petunjuk, jalan

hijau, lampu

penerangan)

tampak tampak

kontras,

harmonis dan

menarik

dengan

lingkungan

sekitar

Sedangkan dari uji reliabilitas untuk mengetahui kehandalan dan konsistensi setiap variabel dimana setiap variabel yang memiliki nilai $\alpha>0.6$ dinyatakan memiliki reliabilitas yang baik (Sujarweni, 2014). Dari hasil pengujian untuk tingkat kepuasan dan kepentingan menunjukkan bahwa variabel memiliki reliabilitas yang baik.

Tabel 5. Hasil uji reliabilitas variabel kepuasan dan kepentingan

\begin{tabular}{lcc}
\hline Variabel & $\begin{array}{c}\text { Cronbach's } \\
\text { Alpha }\end{array}$ & N of Item s \\
\hline Kepuasan & 0,928 & 20 \\
Kepentingan & 0,907 & 20 \\
\hline
\end{tabular}

Untuk mengetahui kualitas pelayanan berdasarkan persepsi pengguna jalur pejalan kaki pada Lingkar Bintaro Jaya Xchange akses stasiun Jurangmangu dilakukan dengan metode Importance Performance Analysis (IPA). Dari hasil rata-rata jawaban responden menunjukkan bahwa tingkat kepuasan rata-rata terhadap fasilitas jalur pejalan kaki adalah 3.605 dan tingkat kepentingan sebesar 4.450.

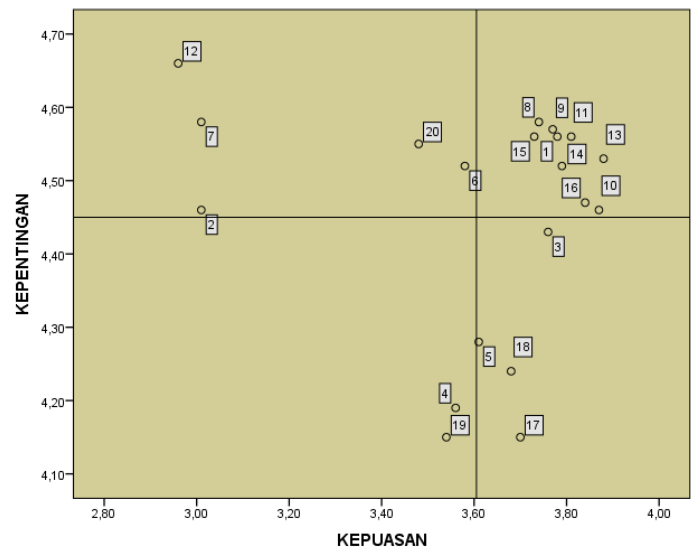

Gambar 6. Kuadran Importance Performance Grid (sumber: olahan SPSS versi 20.0)

Kemudian dilakukan pemetaan dalam kuadran Importance Performance Grid untuk menilai atribut berdasarkan letak kuadran. Berdasarkan Gambar 6 menunjukkan bahwa :

1. Kuadran 1 (high importance, low performance), atribut yang berada pada kuadran ini merupakan atribut yang dianggap penting namun kinerjanya kurang memuaskan, yaitu :
- Adanya kursi atau tempat istirahat untuk pejalan kaki (2)

- Tidak ada penghalang seperti pedagang kaki lima, warung, kendaraan parkir, dll (6)

- Tersedianya jalur khusus untuk penyandang disabilitas (7)

- Ketersediaan jembatan penyebrangan(12)

- Desain fasilitas penunjang (halte, kursi, tempat sampah, rambu petunjuk, jalan hijau, lampu penerang), tampak kontras, harmonis dan menarik dengan lingkungan sekitar (20)

2. Kuadran 2 (high importance, high performance), atribut yang berada pada kuadran ini merupakan atribut yang dianggap penting dan kinerjanya sudah memuaskan, yaitu :

- Pelindung terhadap cuaca (seperti : pohon, kanopi, dll) (1).

- Keberadaan lampu penerang jalan (8).

- Lingkungan yang terhindar dari tindak kriminal (9).

- Pandangan tidak terhalang (10).

- Ketersediaan trotoar yang memadai (11).

- Ketersediaan zebra cross untuk menyebrang (13).

- Keberadaan pembatas atau pemisah jalur pejalan kaki dengan lalu lintas kendaraan (14).

- Tidak ada lubang yang menyebabkan bahaya terperosok atau tersandung (15)

- Permukaan trotoar tidak licin yang mengakibatkan terpeleset (16).

3. Kuadran 3 (low importance, low performance), atribut yang berada pada kuadran ini merupakan atribut yang dianggap kurang penting dan kinerjanya memuaskan, atribut tersebut adalah:

- Keterhubungan trotoar (tidak terputus-putus) (4).

- Desain sarana penyebrangan tampak kontras, harmonis dan menarik dengan lingkungan sekitar (19).

4. Kuadran 4 (low importance, high performance), atribut yang berada pada kuadran ini merupakan atribut yang dianggap kurang penting namun kinerjanya sudah memuaskan, yaitu :

- Lebar trotoar yang memudahkan pergerakan (3).

- Permukaan jalan rata, tidak naik turun dan kemiringan yang cukup landai (5).

- Tidak ada pohon, pot, tiang yang menyebabkan bahaya kecelakaan (17).

- Desain trotoar tampak kontras, harmonis dan menarik dengan lingkungan sekitar (18).

Setelah diketahui atribut yang dianggap penting namun kinerjanya kurang memuaskan, yang didapat dari hasil kuadran 1 metode IPA, maka dilakukan analisis lebih lanjut menggunakan metode QFD untuk bisa mendapatkan rekomendasi perbaikan yang perlu dilakukan. Dalam proses ini melibatkan pihak pengembang kawasan Bintaro sebagai pihak yang 
berkepentingan dalam kebijakan pembangunan fasilitas infrastruktur. Hal ini bertujuan untuk meningkatkan kinerja pelayanan jalur pejalan kaki pada Lingkar Bintaro Jaya Xchange akses stasiun Jurangmangu.

Berdasarkan Gambar.7, memperlihatkan hasil dari Contributions dan Normalized Contributions yang kemudian ditentukan untuk prioritas ranking, dimana pada prioritas ranking ini dapat dilihat perbaikan apa saja yang menjadi konsentrasi dan yang harus diprioritaskan dalam melakukan perbaikan yang dapat menjadi masukan untuk pihak Pengelola Kawasan Bintaro

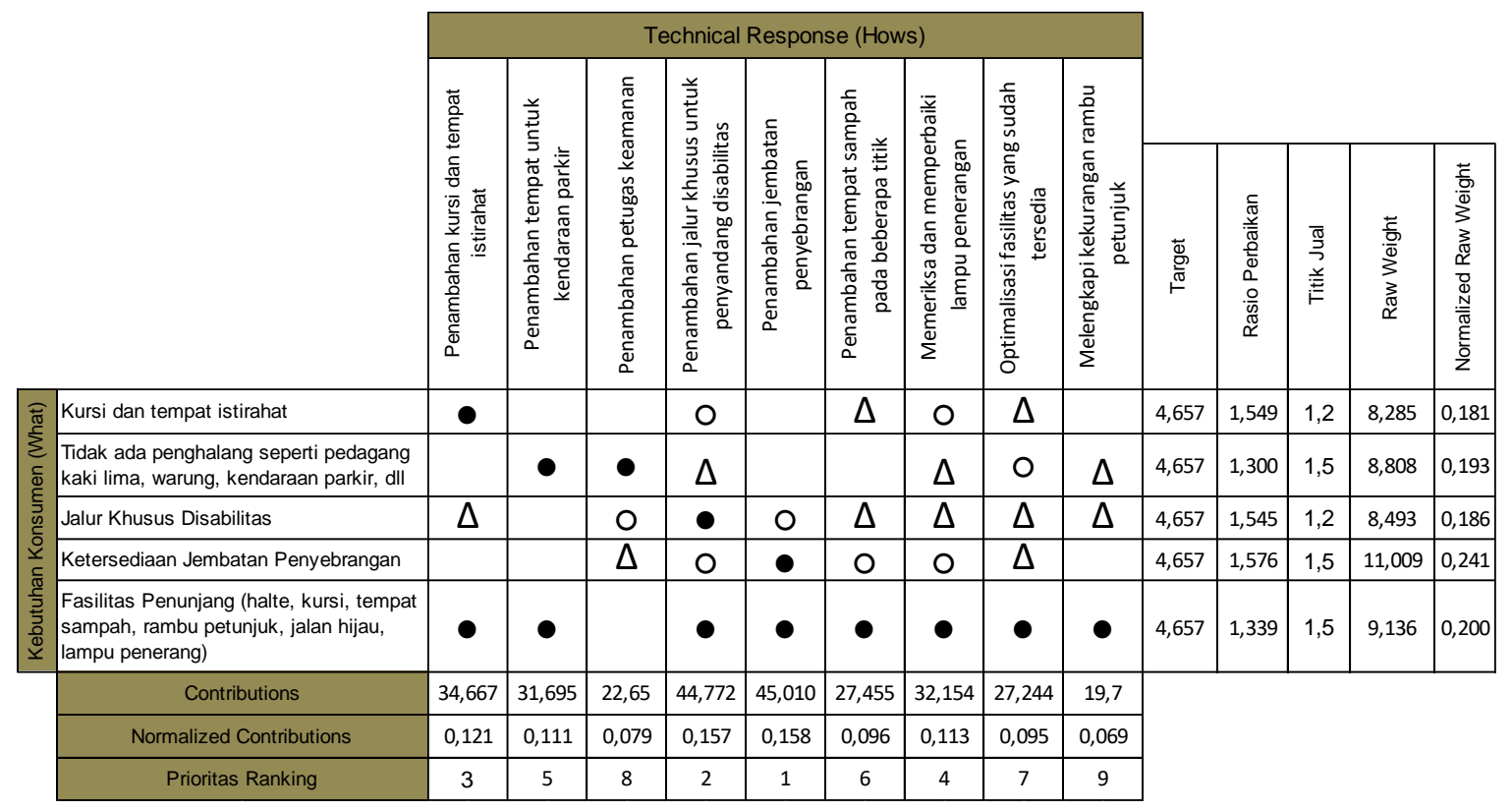

Gambar 7. Hasil Perhitungan Contributions dan Normalized Contributions

Selanjutnya membuat Matrix Korelasi untuk menentukan hubungan antara respon teknis. Penentuan hubungan antar respon menggunakan simbol (++) untuk sangat berhubungan, simbol (+) untuk berhubungan, dan simbol (-) untuk tidak berhubungan.

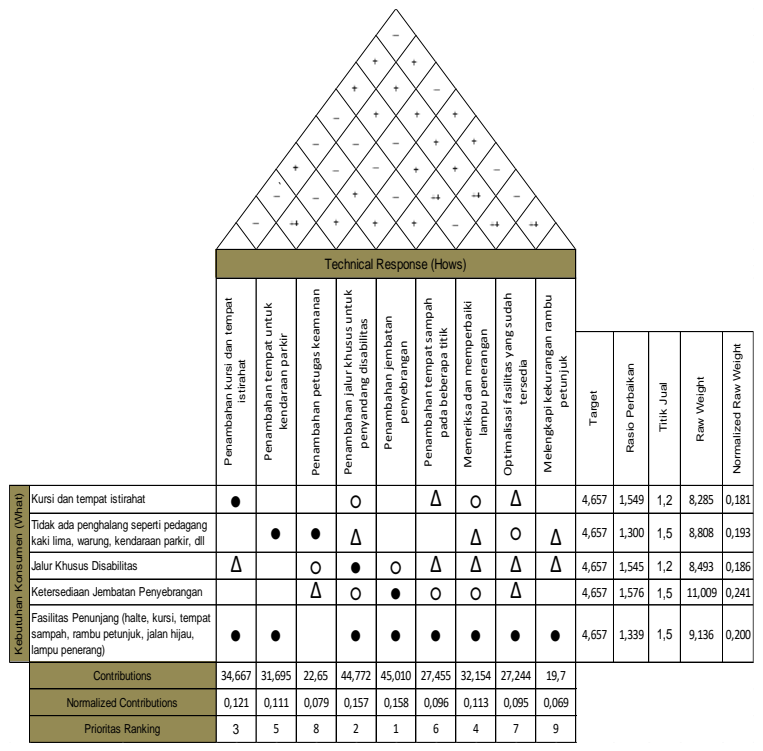

Gambar 8. House Of Quality
Berdasarkan hasil yang sudah didapat pada analisis QFD, dihasilkan rekomendasi yang bertujuan untuk meningkatkan pelayanan pada Jalur pejalan kaki Lingkar Bintaro Jaya Xchange dengan prioritas perbaikan yang berdasarkan nilai Normalized Contributions seperti pada tabel Tabel 6.

Tabel 6. Prioritas Rangking

\begin{tabular}{clc}
\hline $\begin{array}{c}\text { Prioritas } \\
\text { Ranking }\end{array}$ & Rekomendasi Perbaikan & $\begin{array}{c}\text { Nilai } \text { Normalized } \\
\text { Contributions }\end{array}$ \\
\hline 1 & $\begin{array}{l}\text { Penambahan jembatan } \\
\text { penyeberangan }\end{array}$ & 0.158 \\
2 & $\begin{array}{l}\text { Penambahan jalur khusus } \\
\text { untuk penyandang } \\
\text { disabilitas }\end{array}$ & 0.157 \\
3 & $\begin{array}{l}\text { Penambahan kursi dan } \\
\text { tempat istirahat }\end{array}$ & 0.121 \\
4 & $\begin{array}{l}\text { Memeriksa dan } \\
\text { memperbaiki lampu } \\
\text { penerangan }\end{array}$ & 0.113 \\
5 & $\begin{array}{l}\text { Penambahan tempat untuk } \\
\text { parkir }\end{array}$ & 0.111 \\
6 & $\begin{array}{l}\text { Penambahan tempat } \\
\text { sampah pada beberapa } \\
\text { titik }\end{array}$ & 0.096 \\
7 & $\begin{array}{l}\text { Optimalisasi fasilitas yang } \\
\text { sduah tersedia }\end{array}$ & 0.095 \\
8 & $\begin{array}{l}\text { Penambahan petugas } \\
\text { keamanan } \\
\text { Melengkapi kekurangan } \\
\text { rambu petunjuk } \\
\text { Normalized Contributions }\end{array}$ & 0.079 \\
Total Nilai & $\mathbf{1 . 0 0 0}$ \\
\hline & No.069
\end{tabular}




\section{KESIMPULAN}

Berdasarkan Peraturan Menteri Pekerjaan Umum Nomor: 03/PRT/M/2014 jalur pejalan kaki pada akses stasiun Jurangmangu yang terdapat pada Lingkar Bintaro Jaya Xchange memiliki standar kategori A dengan luas jalur pejalan kaki $\geq 12 \mathrm{~m}^{2} /$ orang dengan arus pejalan kaki $<16$ orang/menit/meter. Kinerja pelayanan menunjukkan hasil memuaskan yang ditunjukkan dengan nilai rata-rata 3.605.

Kemudian atribut pelayanan pada jalur pejalan kaki Lingkar Bintaro Jaya Xchange akses stasiun Jurangmangu yang dianggap penting namun kinerjanya kurang memuaskan terdapat pada ketersediaan kursi, tidak adanya penghalang seperti pedagang kaki lima, warung dan kendaraan parkir, tersedianya jalur khusus untuk penyandang disabilitas, ketersediaan jembatan penyebrangan, dan fasilitas penunjang. Rekomendasi perbaikan untuk atribur-atribut pelayanan tersebut didapatkan menggunakan metode QFD yaitu:

1. Penambahan jembatan penyebrangan;

2. Penambahan jalur khusus untuk penyandang disabilitas;

3. Penambahan kursi dan tempat istirahat;

4. Memeriksa dan memperbaiki lampu penerangan;

5. Penambahan tempat untuk kendaraan parker;

6. Penambahan tempat sampah pada beberapa titik;

7. Optimalisasi fasilitas yang sudah tersedia;

8. Penambahan petugas keamanan;

9. Melengkapi kekurangan rambu petunjuk.

\section{REFERENSI}

Cepolina, E. M., Federico, M. \& Paloma, G. R. (2018). Level of service of pedestrian facilities: Modelling human comfort perception in the evaluation of pedestrian behaviour patterns. Transportation Research Part F: Traffic Psychology an Behaviour, 58, 365-381.

Guio, B. F., Duenas, R. D. E., Diaz. M. S. E. (2014). Methodology for Estimating Capacity and Level of Service in Sidewalks. Proceedings Pan-American Conference on Traffic and Transportation Engineering and Logistics Santander, Spain.

Laxman, K. K., Rastogi, R. \& Chandra, S. (2010). Pedestrian Flow Characteristics in Mixed Traffic Conditions. Journal of Urban Planning and Development ASCE, 136(1), 23-33.

PUPR (2014). Peraturan Menteri Pekerjaan Umum Nomor: 03/PRT/M/2014. Perencanaan, Penyediaan, Dan Pemanfaatan Prasarana Dan Sarana Jaringan Pejalan Kaki Dikawasan Perkotaan. Jakarta.

Rifela, L. (2017). Analisis Peningkatan Kinerja Pelayanan Pada Terminal Penumpang Bandar Udara Dengan Metode Quality Function Deployment (QFD). (Studi Kasus: Terminal 3 Ultimate Bandar Udara Internasional Soekarno Hatta). Skripsi. Universitas Pembangunan Jaya.

Shekari, Z. A., Moeinaddini, M. \& Shah, M. Z. (2014). A pedestrian level of service method for evaluating and promoting walking facilities on campus streets, Land Use Policy, 38(1),175-193.
Sujarweni (2014). SPSS Untuk Penelitian. Yogyakarta: Pustaka Baru Press.

Utterman, R. K. (1984). Accommodating the pedestrian. New York: Van Nostrad Reinhold Co.

Yang, L., Jia, H, Juan, Z. \& Zhang. J. (2010). Service Level Classification of Facilities in Passenger Terminals Based on Pedestrian Flow Characteristics Analysis. Proceedings 10th International Conference of Chinese Transportation Professionals, Beijing, China, 2010, pp. 2581-2589. 